\title{
Taxonomic diversity of the genus Cynaeda Hübner, [1825] (Lepidoptera: Crambidae) in Central Asia based on the molecular data
}

\author{
Таксономическое разнообразие рода Cynaeda Hübner, [1825] \\ (Lepidoptera: Crambidae) в Средней Азии \\ на основе молекулярных данных
}

\author{
S.K. Korb \\ C.K. Корб
}

Russian Entomological Society, Nizhny Novgorod Division, P.O.Box 97, Nizhny Novgorod 603009, Russia. E-mail: stanislavkorb@list.ru Русское Энтомологическое Общество, Нижегородское отделение, а/я 97, Нижний Новгород 603009, Россия.

KEY WORDS: snout moths, taxonomy, Central Asia, molecular investigations, COI.

КЛЮЧЕВЫЕ СЛОВА: огнёвки, таксономия, Центральная Азия, молекулярные исследования, цитохромоксидаза субъединица I.

ABSTRACT. First results of the DNA studies within the Cynaeda representatives from Central Asia are submitted. The status of recently described taxon cobaini raised to the species rank: Cynaeda cobaini Korb, 2019, stat.n. The interspecific genetic distance within the genus Cynaeda is 0.038 . The status of the recently described taxon $C$. forsteri komarovi remain unclear; due to its interspecific genetic distance it can be the separated species or the subspecies of $C$. cobaini; this question can be resolved only when the COI sequence of nominate $C$. forsteri will obtained.

РЕЗЮМЕ. Предлагаются первые результаты молекулярных исследований представителей рода Cynaeda в Центральной Азии. Описанному недавно таксону cobaini придан видовой ранг: Cynaeda cobaini Korb, 2019, stat.n., что обосновано значением межвидовой генетической дистанции по фрагменту COI 0.038. Статус недавно описанного таксона C. forsteri komarovi остается неясным; согласно имеющимся различиям в последовательности СОI он может оказаться как самостоятельным видом, так и подвидом C. cobaini. Этот вопрос может быть разрешён только после того, как будет получена последовательность COI номинативной $C$. forsteri.

\section{Introduction}

The genus Cynaeda Hübner, [1825] is a compact group of snout moths of the family Crambidae with very characteristic checkerspot wing pattern. External fea- tures of its species are very variable; genitalia are little bit better key to determine the species but also very variable and structural uniform. Thus mainly the species identification within this group is possible basing on the statistically solid material. It makes the species identification within this group quite difficult. Actually most of the species can be determined with certainty by their distribution (including not only geographical range but also biotope preferences). It was nicely described for Europe and adjacent areas in the recently published book of Slamka [2006]. For Central Asia we have only some data mostly from the revisional work of de Lattin [1951]. Basically all published data about Central Asiatic Cynaeda can be summarized within two phrases. First, the genus Cynaeda represented in Central Asia by only one species (C. furiosa Hampson, 1900). Second, there are possibly some other species represented on this territory.

Starting from 2009 I made a series of moths collecting trips on the territories of Kazakhstan, Kyrgyzstan and Tajikistan. It gave me possibility to add into the Central Asiatic fauna of Lepidoptera at least three more species of Cynaeda: C. dentalis ([Denis et Schiffermller], 1775), $C$. forsteri de Lattin, 1951 and C. gigantea (Staudinger, 1878) [Korb, 2019; Korb, Sinev, 2019]; both have been described from this region as separate subspecies. At the same time I made a DNA sampling of the Cynaeda representatives from the studied territory. The analysis of mtCOI fragments in representatives of Cynaeda DNA sampling showed up that at least one of the described by me taxon have rank of separate species; the status of second one needs further examination. Results of the

How to cite this article: Korb S.K. 2020. Taxonomic diversity of the genus Cynaeda Hübner, [1825] (Lepidoptera: Crambidae) in Central Asia based on the molecular data// Russian Entomol. J. Vol.29. No.2. P.203206. doi: 10.15298/rusentj.29.2.14 
DNA sampling I present in this paper the results of analysis of mtCOI fragments in Central Asiatic Cynaeda.

\section{Materials and methods}

For this work I used DNA samples of the Cytochrome Oxydase Subunit I sequence (COI) both mined from the online databases (GenBank and BOLD) as far as my own. The following four DNA samples have been mined from the online databases: PHLSA611 (BOLD) C. gigantea Italy, PN Majella, Taranta Peligna, Pian di Valle; LON4094 (BOLD) C. pustulalis (Hübner, 1823) Sweden, Oeland, Borgholm, Kolstad; KX071115 (GenBank) C. dentalis ([Denis et Schiffermüller], 1775) Germany, Bavaria, Oberpfalz; LEATA458 (BOLD) $C$. dentalis Austria, Tirol, Nordtirol.
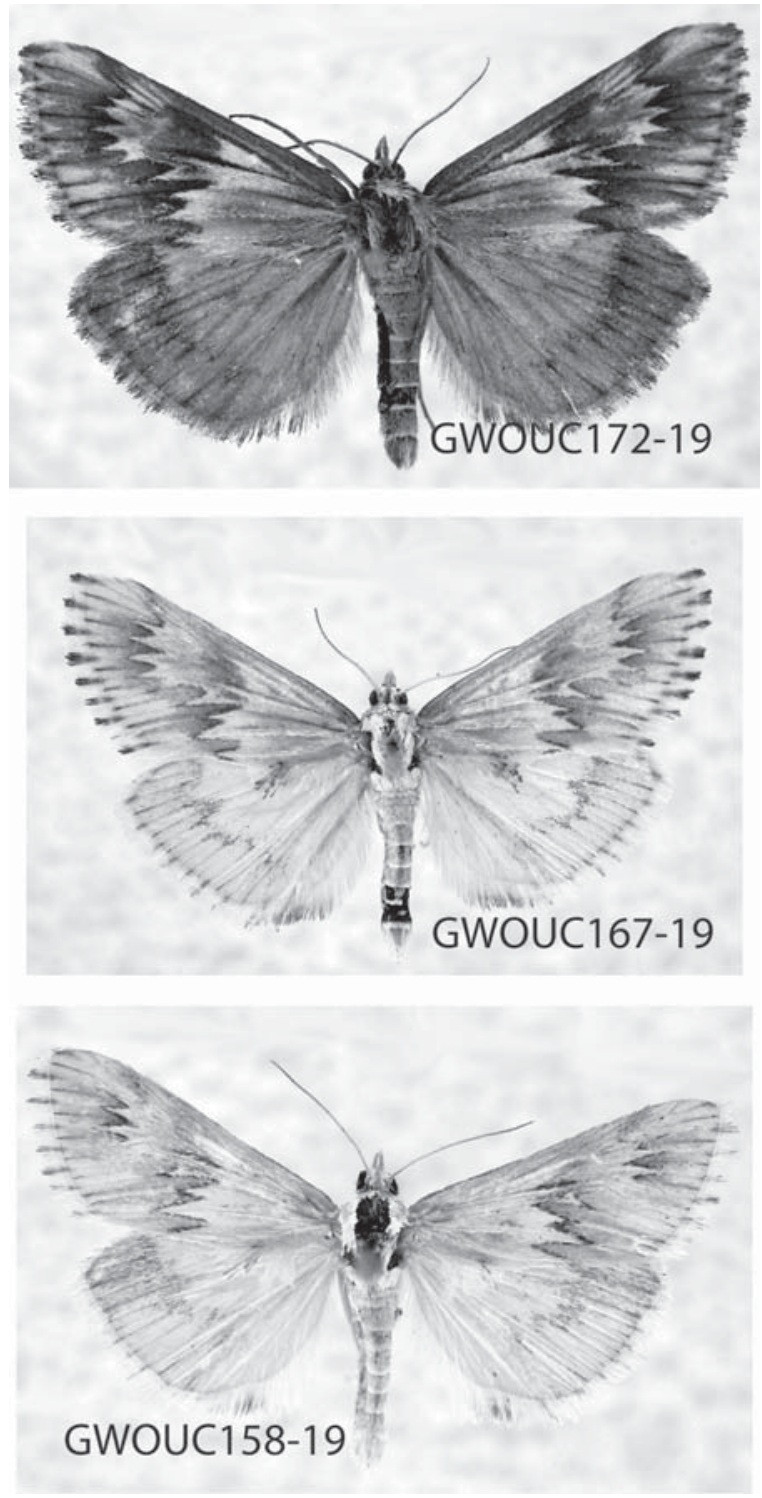

Fig. 1. COI-sampled Central Asiatic Cynaeda specimens.

Рис. 1. Экземпляры Cynaeda из Центральной Азии, у которых изучены образцы COI.
The following three DNA samples have been processed from my data (all BOLD) (Fig. 1): GWOUC158 - C. forsteri komarovi Korb, 2019, West Tian-Shan, Talas Mts., Kara-Buura river; GWOUC167 - C. gigantea cobaini Korb, 2019, Alai Mts., Kyzyl-Eshme valley; GWOUC172 - C. furiosa, Inner Tian-Shan, Dzhumgaltoo Mts., Sary-Kaiky.

As outgroup for phylogenetic reconstruction the sequence of Udea decripetalis (Herrich-Schäffer, 1848) (ABOLA783, BOLD) is used.

DNA sampling and sequencing was processed in the University of Guelph (Canada) by the BOLD program [Ratnasingham, Hebert, 2007]; it was made using processes and protocols described in Huemer et al. [2014]. The length of COI sequences obtained for this analysis is 658 sites.

In total 103 specimens have been studied for comparison with Central Asian ones from Europe, Asia Minor and Near East (see Comparative material examined section below). These ones have been studied morphologically, both external and genitalia (its differences described in detail in Korb [2019] so here are not mentioned). 20 specimens of Central Asiatic Cynaeda have been dissected by the methods, described by Stradomsky [2005].

\section{Comparative material examined.}

Cynaeda forsteri de Lattin, 1951. 6 O', 2728.07.2019, Kyrgyzstan. Talas Prov., Talas Mts., Kara-Buura river coast, $31 \mathrm{~km} \mathrm{~S} \mathrm{of}$ Kluchevka (leg. Korb); $1 \mathrm{O}^{7}, 10.07 .2014$, Moldo-Too Mts., KoroGoo Pass environs (leg. Korb); $1 \bigcirc^{7}, 12.08 .2014$, Kirghizsky Mts., Bishkek environs, Arashan village (leg. Korb) (paratypes of komarovi Korb, 2019); 2 O, 2 +, 1.06.2017, Kazakhstan, Charyn Relic Forest Nature Reserve (leg. Korb).

Cynaeda dentalis ([Denis et Schiffermüller], 1775). $10^{7}$, 13.07.1999, Kyrgyzstan, Northern slope of Issyk-Kul lake, Bosteri (leg. Korb); $1 \mathrm{O}^{7}, 14.07 .2004$, Kyrgyzstan, Naryn (leg. Korb); $1 \mathrm{O}^{7}$, 15.07.2004, Kyrgyzstan, Talass Mts., Chichkan valley (leg. Korb); $1 \mathrm{O}^{7}, 12-13.07 .2015$, Kyrgyzstan, Bishkek environs, Arashan (leg. Korb); 1 ऽ, 13.07.2016, Kyrgyzstan, Toktogul reservoir south shore, Tortkol (leg. Korb); 1 O', 21.07.2016, Kyrgyzstan, Dzhumgaltoo Mts., West Karakol river valley $7 \mathrm{~km} \mathrm{~S}$ of Suusamyr (leg. Korb); $3 \sigma^{7}, 10$ + 22.07 .2016 , Kyrgyzstan, Suusamyrtoo Mts., Kekemeren river valley (leg. Korb); 3 o , 12.07.1973, Russia, Crimea, Simferopol environs (leg. Potopolsky); $10^{7}, 1$,, 2.08 .2008 , Finnland, Uusimaa, Sipo (leg. Korb); 5 ot, 10.09.2013, Germany, near Dresden (leg. Korb); $12 \bigcirc^{7}, 20.06 .2011$, Turkey, Chanakkale Prov., Kayarlar (leg. Korb).

Cynaeda cobaini Korb, 2019, stat.n. 5 O', 14.07.2015, Kyrgyzstan, Alai Mts., Katta-Karakol valley (leg. Korb); $30^{7}$, 2122.07.2019. Kyrgyzstan, Osh Prov., Alai Mts., 6,25 km NNE Kyzyl-Eshme, (leg. Korb) (holotype and paratypes).

Cynaeda furiosa Hampson, 1900. 26 O', 12 ㅇ, 17.07.2015, 21.07.2016, Kyrgyzstan, Dzhumgaltoo Mts., West Karakol river valley $7 \mathrm{~km} \mathrm{~S}$ of Suusamyr (leg. Korb); $2 \sigma^{7}, 2$, 22.07.2016, Kyrgyzstan, Suusamyrtoo Mts., Kekemeren river valley (leg. Korb); 2 O', 10.07.2014, Kyrgyzstan, Moldo-Too Mts., Koro-Goo pass (leg. Korb).

The following software have been used for the DNA analysis: BioEdit ver. 7.2.5, MEGA ver. X.

\section{Results}

The phylogenetic tree (Fig. 2) clearly show that all Central Asian representatives of Cynaeda form their 


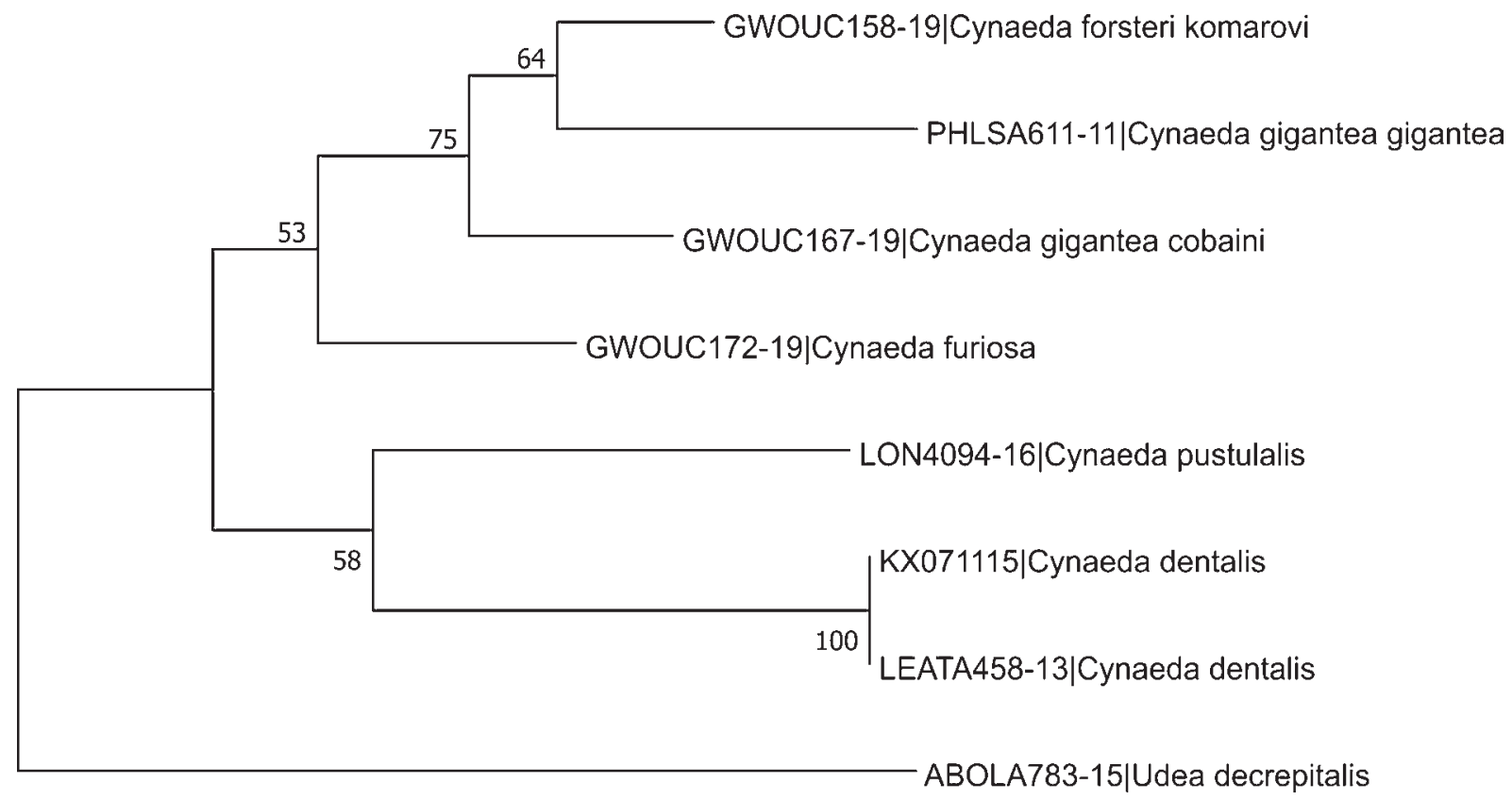

Fig. 2. A phylogenetic tree of the some Palaearctic representatives of Cynaeda based on the COI sequence. The tree was reconstructed by using the Maximum Likelihood method based on the Tamura-Nei-parameter model, 10000 bootstrap-replications. The percentage of trees in which the associated taxa clustered together is shown below/over the branches.

Рис. 2. Филогенетическое древо некоторых палеарктических представителей Супаеда на основе последовательности СОІ. Дерево было реконструировано с использованием метода максимального сходства, основанного на модели параметров Тамура-Ней, 10000 бутстрап-репликаций. Процент деревьев, в которых связанные таксоны сгруппированы вместе, показан ниже / над ветвями.

own cluster branching in which has bootstrap support $5375 \%$. with p-distances over 0.038 . As result of phylogenetic analysis of nucleotide sequences of COI in some representatives of the genus Cynaeda the tree was reconstructed. The cluster with two European taxa is opposite to the cluster joined Central Asiatic taxa. The taxon cobaini which status is reconsidered in present work is represented by separate branch opposed to $C$. forsteri komarovi $+C$. gigantea gigantea cluster with bootstrap support $75 \%$.

According the DNA barcoding testing data [Huemer et al., 2014], in the majority of cases $2 \%$ of COI difference mean a separate species; sometimes it can be more or less of this exact value and it is shown in many papers (for example of small COI differences: Burns et al. [2007] considered genetic distances in 13 nucleotides only enough to separate some skipper butterflies species; for example of big COI differences: Ullah et al. [2017] determined the COI difference between the closely related species of the snout moths within the genus Tylostega Meyrick, 1894 as $3.277 .60 \%$ ). In case of Central Asiatic Cynaeda it is good to consider not only the phylogenetic tree, but also the result of pairwise analysis of COI sequences, because it (especially in comparison with definitely separate species) is more demonstrable.

In the Table $1 \mathrm{I}$ submit the p-distances of COI sequences for the species of Cynaeda. First of all, if we consider the interspecific differences in C. furiosa, $C$. pustulalis and $C$. dentalis, the p-distance is 0.071 between $C$. furiosa $C$. dentalis and 0.070 between $C$. furiosa $C$. pustulalis. The differences between the taxa within Central Asia are lesser than the differences between mentioned species figured above; these parameters between $C$. furiosa and both recently described $C$. gigantea cobaini and $C$. forsteri komarovi are 0.049 and 0.052 respectively. The smallest genetic distances we received between $C$. gigantea cobaini and $C$. forsteri komarovi $(0.038)$ and $C$. gigantea gigantea (0.052).

\section{Discussion}

The differences between European species of $C y$ naeda and Central Asiatic ones are correspond to different intervals. The p-distance vary in the range between 0.079 and 0.084 for Europe; and it is in the range 0.038-0.052 between Cynaeda spp. from Central Asia. Between Central Asiatic and European species the differences are in the range 0.044-0.071. Thus, the minimal interspecific genetic distance within this genus based on current data is $0,038(3,8 \%)$. The p-distance between $C$. gigantea gigantea and $C$. gigantea cobaini is 0.052 , and this is clear evidence that the last taxon is a separate species. Basing on this evidence I raise here the rank of recently described taxon C. gigantea cobaini to the species: Cynaeda cobaini Korb, 2019, stat.n. The morphological differences of this taxon from its closely related $C$. $g i$ - 
Table. Estimates of evolutionary divergence between sequences COI in species of Cynaeda Таблица. Оценки эволюционной дивергенции между последовательностями COI у видов Cynaeda

\begin{tabular}{|l|c|c|c|c|c|c}
\hline Sample & $\begin{array}{l}\text { KX071115 } \\
\text { dentalis }\end{array}$ & $\begin{array}{l}\text { LEATA458 } \\
\text { dentalis }\end{array}$ & $\begin{array}{l}\text { LON4094 } \\
\text { pustulalis }\end{array}$ & $\begin{array}{l}\text { GWOUC158 } \\
\text { forsteri komarovi }\end{array}$ & $\begin{array}{l}\text { GWOUC167 } \\
\text { cobaini }\end{array}$ & $\begin{array}{l}\text { GWOUC172 } \\
\text { furiosa }\end{array}$ \\
\hline $\begin{array}{l}\text { KX071115 } \\
\text { dentalis }\end{array}$ & - & & & & & \\
\hline $\begin{array}{l}\text { LEATA458 } \\
\text { dentalis }\end{array}$ & 0,000 & & & & & \\
\hline $\begin{array}{l}\text { LON4094 } \\
\text { pustulalis }\end{array}$ & 0,079 & 0,079 & & & & \\
\hline $\begin{array}{l}\text { GWOUC158 } \\
\text { forsteri komarovi }\end{array}$ & 0,074 & 0,074 & 0,081 & & & \\
\hline $\begin{array}{l}\text { GWOUC167 } \\
\text { cobaini }\end{array}$ & 0,079 & 0,079 & 0,076 & 0,038 & & \\
\hline $\begin{array}{l}\text { GWOUC172 } \\
\text { furiosa }\end{array}$ & 0,071 & 0,071 & 0,070 & 0,049 & 0,052 & \\
\hline $\begin{array}{l}\text { PHLSA611 } \\
\text { gigantea }\end{array}$ & 0,084 & 0,084 & 0,088 & 0,044 & 0,052 & 0,065 \\
\hline
\end{tabular}

gantea were described in details in its original description: 1) from the internal side of the postmedial line on the forewing in cobaini stat.n. the brown field is located; in gigantea this field is white; 2) postmedial line of the hindwing in cobaini stat.n. with unclear short dents, in gigantea this line have clear, sharp and relatively long dents; 3) cobaini stat.n. in general darker than gigantea; 4) postmedial line of the hindwing in cobaini stat.n. is gray, in gigantea it is brown. The male genitalia differences were not found; the female genitalia were not studied.

The p-distance between $C$. cobaini and $C$. forsteri komarovi is 0,038 ; this parameter is enough to manage both taxa as the separate species, but as we have not enough information to make this judgement uniformly with the above described case, we must wait until at least COI-sequence of nominate $C$. forsteri will be received.

Acknowledgments. I am greatly indebted to Dr. A. Hausmann (Dresden, Germany) for his valuable help with DNA sequencing. I thank Dr S.Y. Sinev (St.-Petersburg, Russia) for his help with Cynaeda determination; my deepest gratitude to Dr E. Komarov and Dr O. Komarova (Volgograd, Russia), Mr A. Samus (Volgograd, Russia), Mr A. Shaposhnikov (Podolsk, Russia), Mr A. Belik (Saratov, Russia), Mr R. Haverinen, Mr J. Packalen and Dr K. Nupponen (Helsinki, Finland) and Mr A. Baryshev (Penza, Russia) for their participation in my expeditions and valuable help within them.

\section{References}

Burns J.M., Janzen D.H., Hajibabaei M., Hallwachs W., Hebert P. 2007. DNA barcodes of closely related (but morphologically and ecologically distinct) species of skipper butterflies (Hesperiidae) can differ by only one to three nucleotides // Journal of the Lepidopterists' Society. Vol.61. P.138-153.

Huemer P., Mutanen M., Sefc K.M., Hebert P. 2014. Testing DNA barcode performance in 1000 species of European Lepidoptera: large geographic distances have small genetic impacts // PLoS One. Vol.9. No.12. e115775.

Korb S.K. 2019. [Two new subspecies of snout moths of the genus Cynaeda Hübner, [1825] (Lepidoptera: Crambidae) from Kyrgyzstan] // Amurian Zoological Journal. Vol.11 P.327-334 [in Russian].

Korb S.K., Sinev S.Y. 2019. [To the knowledge of the snout moths (Lepidoptera: Pyraloidea) of Kazakhstan] // Eversmannia. Vol.5960. P.64-70 [in Russian].

Lattin G. de. 1951. Ueber die Arten der Gattung Cynaeda $\mathrm{Hb}$. (Pyralidae) // Zeitschrift für Lepidopterologie. Bd.1. S.65-84.

Ratnasingham S., Hebert P. 2007. BOLD: The Barcode of Life Data System // Molecular ecology notes. Vol.7. P.355-364.

Slamka F. 2006. Pyraloidea (Lepidoptera) of Europe. Vol. 1. Identification Distribution Habitat Biology. Bratislava: Slamka Press. 138 pp.

Stradomsky B.V. 2005. Blue butterflies of the subfamily Polyommatinae of European Russia, Central and West Caucasia. Rostovon-Don (no publisher recorded). $148 \mathrm{pp}$.

Ullah M., Dong Y., Qiao P., Zhang Y., Yang Z. 2017. Delineating closely related species of Tylostega Meyrick (Lepidoptera: Crambidae: Spilomelinae) from mainland China using DNA barcodes // Mitochondrial DNA Part A. DOI: doi.org/10.1080/24701394. 2017.1419213. 7 pp. 